\title{
Crude glycerin levels in pearl millet-based diets for Nellore young bulls in feedlot
}

\author{
Werney da Silva Moreira1', Fabrícia Rocha Chaves Miotto², João Restle², Regis Luis Missio³, \\ José Neuman Miranda Neiva², Roger Vieira Moreira²
}

\footnotetext{
${ }^{1}$ Universidade Federal do Tocantins, Programa de Pós-graduação em Ciência Animal Tropical, Araguaína, TO, Brasil.

${ }^{2}$ Universidade Federal do Tocantins, Escola de Medicina Veterinária e Zootecnia, Araguaína, TO, Brasil.

${ }^{3}$ Universidade Tecnológica Federal do Paraná, Departamento de Agronomia, Pato Branco, PR, Brasil.
}

\begin{abstract}
The objective of this study was to find the best level of inclusion of crude glycerin $(0,60,120$, and $240 \mathrm{~g} \mathrm{~kg}^{-1}$ of dry matter of diet) in substitution of pearl millet in a feedlot diet. Twenty-eight Nellore young bulls with mean age of 18 months and average weight of $357 \pm 23.56 \mathrm{~kg}$ were used. The animals were distributed in a completely randomized design with four treatments and seven replications. The intakes of dry matter, crude protein, neutral detergent fiber, and total digestible nutrients were similar among the dietary levels of crude glycerin. The ether extract intake decreased with increase in the levels of crude glycerol in the diets. Apparent digestibility of dry matter, crude protein, and extract ether was similar among the dietary crude glycerin levels. Apparent digestibility of neutral detergent fiber was lower in the diets with inclusion of crude glycerin in relation the other diets. The increase in the levels of crude glycerin did not affect the total digestible nutrients content of the diets. Average daily gain increased linearly with the increase in crude glycerin. Feed conversion was not altered by the increase in the levels of crude glycerin in the diets. The dietary increase in crude glycerin level did not affect the carcass characteristics. The inclusion of up to $240 \mathrm{~g} \mathrm{~kg}^{-1}$ of crude glycerin in pearl millet grain-based diets for feedlot-finished Nellore young bulls increases average daily gain, but does not change the main carcass characteristics of economic importance.
\end{abstract}

Key Words: by-products, digestibility, finishing, glycerol, intake, weight gain

\section{Introduction}

Biodiesel is a promising alternative to fossil fuels as it reduces the emissions of $\mathrm{CO}_{2}, \mathrm{SO}_{2}$, and $\mathrm{SO}_{3}$. Biodiesel is obtained mainly from vegetable oils, which, with the addition of a basic catalyst and in the presence of methanol or ethanol, are transesterified, forming three molecules of methyl esters (biodiesel), releasing one molecule of glycerol, called low-grade glycerol or crude glycerol. This glycerol undergoes an acid treatment to neutralize the catalyst and remove the formed fatty acids, containing around $80 \%$ glycerol, in addition to water, methanol, and dissolved salts (Mota et al., 2009; Tan et al., 2013).

The increase in the demand for biodiesel, which corresponded to $7 \%$ of the fossil diesel in 2014 , reflects in greater supply of crude glycerol, which leads to the need for applications to be found for this by-product. In this context, because it is the largest commercial herd of the world

Received July 10, 2015 and accepted October 21, 2015

Corresponding author: regisluismissio@gmail.com

http://dx.doi.org/10.1590/S1806-92902016000100005

Copyright (C) 2016 Sociedade Brasileira de Zootecnia. This is an Open Access article distributed under the terms of the Creative Commons Attribution License (http://creativecommons.org/licenses/by/4.0/), which permits unrestricted use, distribution, and reproduction in any medium, provided the original work is properly cited.
(Anualpec, 2014), the Brazilian cattle herd shows great potential for the commercial absorption of this by-product, providing an environmentally appropriate destination for this by-product, in addition to contributing to reducing feed costs due to the lower price of this by-product compared with those traditionally used in animal feeding. The use of crude glycerol in animal feeding, in this sense, has been normally researched as a substitute for corn grain (Chanjula et al., 2014; Van Cleef et al., 2014).

Despite the intensification of studies with this feedstuff, the obtained results have been contradictory (Lage et al., 2010; Françozo et al., 2013; Van Cleef et al., 2014). In general, the animal performance is expected to improve because the crude glycerol improves the energy use efficiency by the animal, as was observed by Françozo et al. (2013). However, this improvement in the animal performance depends, among other factors, on the feedstuffs that make up the diets (Hales et al., 2013). The pearl millet grain, in this context, is utilized as a substitute for the corn grain, which, at times when the corn prices rise, allows for a reduction in the feed cost in feedlots, besides providing similar performance to cattle compared to the corn grain (Hill et al., 1996; Silva et al., 2014).

The objective of the present study was to find the best level of inclusion of crude glycerin replacing pearl millet in a feedlot diet. 


\section{Material and Methods}

The experiment was conducted from July to September 2012 in the county of Araguaína - TO, Brazil. The procedures performed in this experiment were approved by the Ethics Committee for Animal Experimentation of Universidade Federal do Tocantins, under number 23101003926/2012-66.

Twenty-eight 18-month-old Nellore young bulls, with an initial average body weight of $357 \pm 23.56 \mathrm{~kg}$, were used. Animals were kept in individual concrete floor stalls $\left(12 \mathrm{~m}^{2}\right)$ with troughs for food and water. At the beginning of the adaptation phase ( $21 \mathrm{~d})$, all animals were dewormed and supplemented with vitamins A, D, and E. Four diets were formulated to meet the requirements for growth and finishing with dry matter intake of $24 \mathrm{~g} \mathrm{~kg}^{-1}$ of body weight (BW) according to NRC (1996). These diets included elephant-grass silage as forage and concentrates composed mainly of ground pearl millet, soybean meal, and crude glycerol (Table 1).

Elephant grass forage was harvested and ensiled with 70 days of regrowth and shredded to obtain the particle size of $8-10 \mathrm{~mm}$. According to the manufacturer's data, the crude glycerol used had $899.2 \mathrm{~g} \mathrm{~kg}^{-1}$ fresh matter; $11.9 \mathrm{~g}$ ether extract $\mathrm{kg}^{-1}$ of dry matter (DM), $78.6 \mathrm{~g}$ mineral matter $\mathrm{kg}^{-1}$ DM; 803.5 g glycerol kg-1 DM; $<0.001 \mathrm{~g}^{-1}$ methanol $\mathrm{kg}^{-1}$ $\mathrm{DM}$; and $74.7 \mathrm{~g}$ chloride $\mathrm{kg}^{-1} \mathrm{DM}$. The treatments were diets containing crude glycerol at increasing levels $(0,60$, 120 , and $240 \mathrm{~g}$ of crude glycerol $\mathrm{kg}^{-1}$ of the DM of diets), maintaining the ratio of $20 \%$ forage (Table 2).

Animal performance was measured for 84 days, which consisted of 21 days of adaptation to diet and stalls and 73 days of data collection. The animals were fed at $12.00 \mathrm{~h}$ and $17.00 \mathrm{~h}$ ad libitum, i.e., adjusted to provide $10 \%$ as orts of the offered feed (dry matter basis). Animals after fasting for 14-16 $\mathrm{h}$ were weighed at the beginning and end of the evaluation period. To obtain the average feed intake, feed and orts were also weighed daily. Throughout the performance test, samples of ingredients and orts from each animal and

Table 1 - Chemical composition of ingredients $\left(\mathrm{g} \mathrm{kg}^{-1}\right.$ of dry matter)

\begin{tabular}{lccc}
\hline & \multicolumn{3}{c}{ Ingredient } \\
\cline { 2 - 4 } & $\begin{array}{c}\text { Elephant } \\
\text { grass silage }\end{array}$ & $\begin{array}{c}\text { Ground pearl } \\
\text { millet grain }\end{array}$ & $\begin{array}{c}\text { Soybean } \\
\text { meal }\end{array}$ \\
\hline Dry matter $\left(\mathrm{g} \mathrm{kg}^{-1}\right.$ as fed) & 269.20 & 863.40 & 833.70 \\
Ash & 65.40 & 17.60 & 65.00 \\
Crude protein & 45.40 & 117.70 & 463.10 \\
Ether extract & 16.80 & 42.30 & 14.80 \\
Neutral detergent fiber & 683.10 & 132.00 & 141.50 \\
Total carbohydrates & 872.40 & 822.40 & 457.10 \\
Non-fibrous carbohydrates & 189.30 & 690.00 & 315.60 \\
\hline
\end{tabular}

ingredients of feed concentrates from mixture preparations were collected weekly to provide representative samples. The samples were placed in plastic bags, labeled and stored in a freezer at $-10{ }^{\circ} \mathrm{C}$ until laboratory analysis.

Feces for the digestibility trial were collected during the last three days of the experimental period. The collection of stool (300 g) was performed manually (one person for four animals), after spontaneous defecation and before the fecal bolus reached the floor of the pen, with animals monitored from $06.00 \mathrm{~h}$ until the collection of the sample from the last animal. Eventually, samples were collected immediately after the fecal bolus was deposited on the floor of the pen (cleaned daily for this test), discarding the portion in contact with this surface. For the digestibility trial and analysis of nutrients, samples were pre-dried in a forced ventilation oven at $55{ }^{\circ} \mathrm{C}$ for $72 \mathrm{~h}$ and ground in a $1-\mathrm{mm}$ sieve. From the three ground samples, a composite sample was made and stored in plastic containers for subsequent laboratory analyses. The fecal dry matter excretion was estimated using indigestible neutral detergent fiber (iNDF) according to the methodology of Cochran et al. (1986). The iNDF contents of the samples of feces, feed (roughage and ingredients of the concentrate), and leftovers were obtained after in situ rumen incubation for $240 \mathrm{~h}$ (Casali et al., 2008). The fecal output ( $\mathrm{kg}$ of $\mathrm{DM}$ day $^{-1}$ ) was calculated as: iNDF intake/iNDF in feces. The digestibility was calculated by the expression: apparent digestibility of nutrients $=[$ (nutrient intake - nutrients excreted)/nutrient intake].

Table 2 - Composition of experimental diets

\begin{tabular}{|c|c|c|c|c|}
\hline \multirow{2}{*}{ Item ( $\mathrm{g} \mathrm{kg}^{-1}$ of dry matter) } & \multicolumn{4}{|c|}{$\mathrm{g} \mathrm{kg}^{-1}$ of crude glycerol } \\
\hline & 0 & 60 & 120 & 240 \\
\hline \multicolumn{5}{|c|}{ Proximate composition } \\
\hline Elephant grass silage & 200.00 & 200.00 & 200.00 & 200.00 \\
\hline Ground pearl millet grain & 777.90 & 650.10 & 523.70 & 364.50 \\
\hline Crude glycerol & - & 60.00 & 120.00 & 240.00 \\
\hline Soybean meal & 37.00 & 61.20 & 87.00 & 138.00 \\
\hline Limestone & 12.00 & 12.00 & 12.00 & 11.50 \\
\hline Urea & 4.00 & 4.00 & 4.00 & 4.00 \\
\hline Mineral mixture ${ }^{1}$ & 7.00 & 7.00 & 7.00 & 7.00 \\
\hline Sodium chloride & 3.00 & 3.00 & 3.00 & 3.00 \\
\hline Ammonium sulfate & 0.40 & 0.40 & 0.40 & 0.40 \\
\hline Monensin sodium & 0.30 & 0.30 & 0.30 & 0.30 \\
\hline Virginiamycin & 0.30 & 0.30 & 0.30 & 0.30 \\
\hline \multicolumn{5}{|c|}{ Chemical composition } \\
\hline Dry matter, $\mathrm{g} \mathrm{kg}^{-1}$ as fed & 746.00 & 735.00 & 722.00 & 674.00 \\
\hline Ash & 43.00 & 46.00 & 47.00 & 57.00 \\
\hline Crude protein & 110.00 & 115.00 & 114.00 & 113.00 \\
\hline Ether extract & 34.00 & 33.60 & 29.40 & 24.00 \\
\hline Neutral detergent fiber & 229.00 & 237.00 & 228.00 & 203.00 \\
\hline Total carbohydrates & 810.00 & 804.00 & 808.00 & 804.00 \\
\hline Non-fibrous carbohydrates & 580.00 & 566.00 & 579.00 & 601.00 \\
\hline
\end{tabular}


Standard procedures of AOAC (1995) were adopted to obtain the following components from the feed, orts, and fecal samples: dry matter, mineral matter, crude protein, and ether extract. Neutral detergent fiber was determined according to the methodology of Van Soest et al. (1991). Total carbohydrates, non-fiber carbohydrates, and total digestible nutrients were estimated according Sniffen et al. (1992), as follows: total carbohydrates $=1,000-$ (crude protein + ether extract + mineral matter); non-fiber carbohydrates $=1,000-($ total carbohydrates + neutral detergent fiber); total digestible nutrients $=$ digestible crude protein $+($ digestible ether extract $\times 2.25)+$ digestible neutral detergent fiber + digestible total carbohydrates.

At the end of the feedlot period, the animals were slaughtered at a commercial slaughterhouse with supervision of the Brazilian Federal Inspection Service. Prior to the slaughter, the animals were subjected to fasting for 14-16 h. After slaughter, carcasses were identified, divided in half, and weighed. After the carcasses were washed and cooled in a cold room at $2{ }^{\circ} \mathrm{C}$ for $24 \mathrm{~h}$, they were weighed again. The carcasses were evaluated for conformation score according to the methodology of Müller (1987), in which: 1-3: inferior; 4-6: bad: 7-9: regular; 10-12: good; 13-15: very good; 16-18: superior. A cut was made on the right half carcass between the 11th and 12th ribs, exposing the longissimus dorsi muscle, where its area and fat thickness were determined.

The experimental design was completely randomized with four treatments (levels of crude glycerin in the diets) and seven replicates (animals). The Shapiro Wilk test was performed to evaluate the normality and Cochran and Bartlett's test was used to evaluate the homogeneity of variances, and whenever necessary the data were transformed using logarithmic function. The data were subjected to analysis of variance and contrast by mixed model methodology (Littell et al., 2006). Sum of squares of treatments in contrasts analysis was decomposed into three

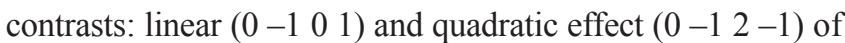
crude glycerin levels and diets with or without inclusion of crude glycerol $(3-1-1-1)$. The mathematical model is represented by $\mathrm{Y}_{\mathrm{ijk}}=\mu+\mathrm{T}_{\mathrm{i}}+\mathrm{M}_{\mathrm{j}}+\mathrm{e}_{\mathrm{ijk}}$, in which $\mu=$ overall mean; $\mathrm{T}_{\mathrm{i}}=$ effect of the diets; $\mathrm{M}_{\mathrm{j}}=$ effect of the covariate; and $\mathrm{e}_{\mathrm{ijk}}=$ residual random error. When it was not significant, the effect of the covariate was withdrawn from the model. For probability of type I error, $\alpha=0.05$. The statistical analysis was conducted using SAS software (Statistical Analysis System, version 9.1).

\section{Results}

The intakes of dry matter, crude protein, neutral detergent fiber, and total digestible nutrients were similar $(\mathrm{P}>0.05)$ among diets (Table 3 ). The increased dietary crude glycerin level reduced the ether extract intake linearly $(\mathrm{P}<0.05)$, and the intake of this dietary fraction was higher for the diet without glycerol. The apparent digestibility coefficients of dry matter and other nutrients, except for neutral detergent fiber, were similar $(\mathrm{P}>0.05)$ among diets. The digestibility

Table 3 - Apparent digestibility and intake of nutrients, and total digestible nutrients of diets according to the dietary crude glycerin levels

\begin{tabular}{|c|c|c|c|c|c|c|c|c|}
\hline \multirow{2}{*}{ Item } & \multicolumn{4}{|c|}{$\mathrm{g} \mathrm{kg}^{-1}$ of crude glycerin } & \multirow{2}{*}{$\mathrm{CV}(\%)$} & \multicolumn{3}{|c|}{ Contrast, P-value } \\
\hline & 0 & 60 & 120 & 240 & & $\mathrm{~L}$ & Q & 0 vs. CG \\
\hline \multicolumn{9}{|c|}{ Intake $\left(\mathrm{kg} \mathrm{day}{ }^{-1}\right)$} \\
\hline Dry matter & 7.95 & 7.86 & 8.05 & 7.91 & 8.40 & 0.972 & 0.831 & 0.957 \\
\hline Crude protein & 0.89 & 0.92 & 0.93 & 0.90 & 8.62 & 0.840 & 0.322 & 0.617 \\
\hline Ether extract & 0.30 & 0.29 & 0.24 & 0.19 & 8.38 & $<0.001$ & 0.737 & $<0.001$ \\
\hline Neutral detergent fiber & 1.74 & 1.83 & 1.79 & 1.64 & 8.68 & 0.129 & 0.111 & 0.829 \\
\hline Total digestible nutrients & 5.78 & 5.19 & 5.24 & 5.82 & 12.35 & 0.503 & 0.053 & 0.299 \\
\hline \multicolumn{9}{|c|}{ Intake ( $\mathrm{g} \mathrm{kg}^{-1}$ of body weight) } \\
\hline Dry matter & 19.68 & 19.40 & 20.01 & 19.22 & 7.80 & 0.714 & 0.601 & 0.859 \\
\hline Crude protein & 2.24 & 2.26 & 2.30 & 2.17 & 8.08 & 0.428 & 0.300 & 0.973 \\
\hline Ether extract & 0.76 & 0.72 & 0.61 & 0.48 & 9.56 & $<0.001$ & 0.833 & $<0.001$ \\
\hline Neutral detergent fiber & 4.28 & 4.51 & 4.44 & 4.00 & 8.52 & 0.084 & 0.058 & 0.836 \\
\hline Total digestible nutrients & 14.30 & 12.80 & 13.04 & 14.15 & 12.23 & 0.673 & 0.076 & 0.250 \\
\hline \multicolumn{9}{|c|}{ Apparent digestibility ( $\mathrm{kg} \mathrm{kg}^{-1}$ of DM) } \\
\hline Dry matter & 0.70 & 0.65 & 0.69 & 0.74 & 9,79 & 0.128 & 0.583 & 0.577 \\
\hline Crude protein & 0.71 & 0.69 & 0.71 & 0.77 & 9.64 & 0.227 & 0.655 & 0.451 \\
\hline Ether extract & 0.68 & 0.62 & 0.50 & 0.60 & 19.82 & 0.088 & 0.119 & 0.067 \\
\hline Neutral detergent fiber & 0.46 & 0.38 & 0.41 & 0.40 & 11.47 & 0.278 & 0.078 & 0.006 \\
\hline \multicolumn{9}{|c|}{ Total digestible nutrients content of diets ( $\mathrm{g} \mathrm{kg}^{-1}$ of DM) } \\
\hline Total digestible nutrients & 725.22 & 661.36 & 675.65 & 735.20 & 10.18 & 0.464 & 0.191 & 0.230 \\
\hline
\end{tabular}

Ether extract intake $\left(\mathrm{EE}, \mathrm{kg} \mathrm{day}^{-1}\right)=0.3076-0.00477 \mathrm{CG}$; EE intake $\left(\mathrm{g} \mathrm{kg}^{-1}\right.$ of body weight $)=0.7763-0.00123 \mathrm{CG}$

$\mathrm{CV}$ - coefficient of variation; L - linear effect of crude glycerin level (CG); Q - quadratic effect of crude glycerin level; 0 vs. CG - diets with vs. diets without crude glycerin. 
of neutral detergent fiber was greater for diets with crude glycerin in relation the diets without inclusion of the byproduct. The increase in the crude glycerin level did not change $(\mathrm{P}>0.05)$ the total digestible nutrient content of the diets.

The average daily gain increased and the feed conversion decreased linearly $(\mathrm{P}<0.05)$ as the level of crude glycerin in the diet was increased (Table 4). Final body weight, however, manifested only an upward trend $(\mathrm{P}=0.08)$ with the levels of crude glycerin in the diet, which was also found for hot carcass weight. The other carcass traits were not changed $(\mathrm{P}<0.05)$ by the dietary crude glycerin levels.

\section{Discussion}

The lack of variation in dry matter intake, and consequently in the intakes of crude protein, neutral detergent fiber, and total digestible nutrients, agreed with most of the studies in the literature (Leão et al., 2012; Françozo et al., 2013; Chanjula et al., 2014), which demonstrated that the ingestion of these dietary fractions was not changed with the inclusion of up to $30 \%$ crude glycerin in the diet (dry matter basis). However, results demonstrating a similarity in dry matter intake with the increase in the dietary level of crude glycerin for ruminants are not unanimous in the literature. In this regard, Parsons et al. (2009) found a decrease in feed intake when crude glycerin replaced $16 \%$ of the flaked corn from the diet fed to feedlot heifers and suggested that the high concentrate level of the diet $\left(960 \mathrm{~g} \mathrm{~kg}^{-1} \mathrm{DM}\right)$ was unfavorable to the rumen environment (accumulation of lactate), which was aggravated by the addition of glycerin.
According to Trabue et al. (2007), the accumulation of lactate in the rumen affects the crude glycerin fermentation routes by the rumen microorganisms, and consequently the feed intake is changed. Leão et al. (2012) stated that it is possible that the feasibility of using greater levels of crude glycerin in the diet depends on the proper supply of effective fiber, which, in the present study, was met with the $200 \mathrm{~g}$ of dry matter of elephant grass silage per kilogram of dietary dry matter. These researchers (Leão et al., 2012) also emphasized that the contents of salt, ether extract, and methanol of the crude glycerin are determinants of feed intake, and when in excess they compromise feed intake. The composition of the crude glycerol ( $7.47 \%$ salt, $<0.01 \%$ methanol, and $1.19 \%$ ether extract) utilized in this study met the recommendations of the Ministry of Agriculture, Livestock and Supply (MAPA), exempting it from altering dry matter intake.

The reduction in ether extract intake with the increase in the level of crude glycerin replacing the ground pearl millet is associated with the fact that the ether extract of this by-product was $255.5 \%$ lower than the ether extract content of the pearl millet. These results were similar to those obtained by Leão et al. (2012), who, evaluating crude glycerin levels $(0,6,12$, and $24 \%)$, found a linear decrease in ether extract intake by cull cows, which was attributed to the lower ether extract content of crude glycerin in relation to corn. Lage et al. (2010), however, found that the ether extract intake by lambs increased with the inclusion of up to $10.81 \%$ crude glycerin in the diets, which was attributed to the fact that the crude glycerin contained a high level of fatty acids (46.48\%). Crude glycerin is produced from the transesterification of triglycerides with alcohol (Morin

Table 4 - Performance and carcass characteristics of Nellore young bulls fed crude glycerin levels

\begin{tabular}{|c|c|c|c|c|c|c|c|c|}
\hline \multirow{2}{*}{ Item } & \multicolumn{4}{|c|}{$\mathrm{g} \mathrm{kg}^{-1}$ of crude glycerin } & \multirow{2}{*}{$\mathrm{CV}(\%)$} & \multicolumn{3}{|c|}{ Contrast, P-value } \\
\hline & 0 & 60 & 120 & 240 & & $\mathrm{~L}$ & Q & 0 vs. $\mathrm{CG}$ \\
\hline \multicolumn{9}{|c|}{ Performance } \\
\hline IW & 337.30 & 356.80 & 348.70 & 345.00 & 8.17 & - & - & - \\
\hline FW & 438.30 & 451.20 & 445.00 & 464.30 & 6.10 & 0.356 & 0.780 & 0.694 \\
\hline $\mathrm{ADG}$ & 1.24 & 1.26 & 1.41 & 1.53 & 16.64 & 0.048 & 0.656 & 0.276 \\
\hline $\mathrm{FC}$ & 6.51 & 6.39 & 5.65 & 5.32 & 14.51 & 0.042 & 0.632 & 0.176 \\
\hline \multicolumn{9}{|c|}{ Carcass characteristic } \\
\hline HCW & 238.27 & 242.82 & 244.40 & 251.57 & 5.46 & 0.161 & 0.966 & 0.124 \\
\hline $\mathrm{CCW}$ & 230.72 & 236.88 & 237.39 & 242.98 & 5.41 & 0.179 & 0.829 & 0.546 \\
\hline $\mathrm{HCY}$ & 0.54 & 0.54 & 0.55 & 0.54 & 2.44 & 0.556 & 0.896 & 0.945 \\
\hline $\mathrm{CCY}$ & 0.53 & 0.52 & 0.53 & 0.52 & 2.22 & 0.816 & 0.702 & 0.551 \\
\hline DL & 31.08 & 24.24 & 28.66 & 32.68 & 31.25 & 0.445 & 0.327 & 0.712 \\
\hline FK & 4.50 & 4.00 & 4.75 & 3.33 & 18.84 & 0.375 & 0.855 & 0.205 \\
\hline LDA & 57.06 & 55.97 & 57.62 & 57.10 & 9.27 & 0.830 & 0.985 & 0.947 \\
\hline $\mathrm{CC}$ & 10.00 & 10.50 & 10.50 & 10.00 & 9.97 & 0.958 & 0.995 & 0.657 \\
\hline
\end{tabular}

IW - initial weight $(\mathrm{kg}) ; \mathrm{FW}$ - final weight $(\mathrm{kg}) ; \mathrm{ADG}$ - average daily gain $\left(\mathrm{kg} \mathrm{day}^{-1}\right)=1.24+0.0092 \mathrm{CG}$; FC - feed conversion $\left(\mathrm{kg}\right.$ of dry matter kg ${ }^{-1}$ of weight gain) $=6.501-0.0415 \mathrm{CG}$; $\mathrm{HCW}$ - hot carcass weight ( $\mathrm{kg})$; HCY - hot carcass yield $\left(\mathrm{kg} \mathrm{kg}^{-1}\right)$; CCW - cold carcass weight; CCY - cold carcass yield; DL - drip loss ( $\left.\mathrm{g} \mathrm{kg}{ }^{-1}\right)$; FK - fat thickness (mm); LDA - longissimus dorsi area; CC - carcass conformation (scores).

CV - coefficient of variation; L - linear effect of crude glycerin level (CG); Q - quadratic effect of crude glycerin level; 0 vs. CG - diets with vs. diets without crude glycerin. 
et al., 2007), and thus the ether extract content of this byproduct depends on the levels of fatty acids remaining from the transesterification process. Thus, the ether extract content of crude glycerin and of the feedstuffs to be replaced by this by-product are determinants of the intake of ether extract by cattle from the same animal category fed diets with different levels of crude glycerin.

Crude glycerin has high digestibility because most of the glycerol, its main component, is quickly fermented by rumen microorganisms or escapes ruminal fermentation, being then absorbed into the rumen epithelium (Trabue et al., 2007; Donkin, 2008). However, while glycerin can increase the digestibility of diets because of its higher digestibility, its inclusion causes a reduction of the digestibility of the fiber fraction of diets because of the negative impact on the population of rumen fibrolytic bacteria (Abo El-Nor et al., 2010; Abughazaleh et al., 2011). In this study, it is believed that the positive and negative aspects of crude glycerin on the apparent digestibility of diets were offset, resulting in no effect of crude glycerin levels on the digestibility coefficients of dry matter, crude protein, ether extract, and total digestible nutrients of the diets. Additionally, the lack of variation in dry matter intake also explains the similar digestibility coefficients of dry matter, crude protein, and ether extract of the diets. The elevation of the intake level, in this regard, can increase the passage rate, reducing the permanence time of the particles in the reticulorumen and the digestibility of the feeds, as stressed by Missio et al. (2012). The reduction in intake, however, can cause the opposite effect, increasing the permanence time of the digesta in the reticulorumen and the digestibility of the diets (Oba and Allen, 1999).

The results obtained for the apparent digestibility of the diets were partially similar to those obtained by Chanjula et al. (2014), who did not find alterations in the digestibility coefficients of diets with 5,10 , and $20 \%$ crude glycerin supplied to goats. Van Cleef et al. (2014), on the other hand, found an increase in the digestibility coefficients of crude protein and reduction of the fibrous fraction with an increase in the crude glycerol level of diets for Nellore young bulls $(0,7.5,15,22.5$, and $30 \%$ of the dry matter), which was attributed, respectively, to increased cottonseed meal to fix the protein content of the diets and reduction of the rumen fibrolytic bacteria. The mechanism of action of glycerol on the fibrolytic bacteria, according to Van Cleef et al. (2014), is not elucidated yet, but may be related to the formation of an unfavorable rumen environment (osmolarity and $\mathrm{pH})$; to the physical protection of fibrous fraction, which prevents the adherence of bacteria; and to the preference or competition for other substrates - in this case, glycerol.
The increase in average daily gain obtained in this study can be explained by the improvement in the energy efficiency with the elevation of the dietary crude glycerol content. According to Donkin (2008), glycerol is fermented in the rumen to short-chain fatty acids, such that 50 to $70 \%$ of the glycerol disappears in the rumen in up to $4 \mathrm{~h}$, leading to an increase in propionate production. The increase in the synthesis of these volatile fatty acids is responsible for the reduction in the amount of carbon and hydrogen available for the production of methane gas, with a consequent improvement in the efficiency of the use of energy by the animal (Trabue et al., 2007; Chanjula et al., 2014). In addition, because of its liquid state, crude glycerin can be absorbed and metabolized in the liver, used for the maintenance of the plasma glucose levels (Krehbiel, 2008). The increase in the availability of glucose can represent a gluconeogenic-amino-acid-sparing effect, increasing the protein anabolism (Lobley, 1992), which also explains the greater weight gains by cattle fed crude glycerol.

The presented results were similar to those obtained by Françozo et al. (2013), who evaluated levels of crude glycerin $(0,5$, and $10 \%$ of the dry matter) and found an increase in the average daily gain of Nellore young bulls. Likewise, Hales et al. (2013) found that the replacement of $7.5 \%$ (dry matter basis) of alfalfa hay with crude glycerin increased the weight gain of steers but did not observe alterations in this variable when crude glycerin substituted the flaked corn in the diet. On the other hand, Leão et al. (2012) did not find alterations in the average daily gain of beef cattle with crude glycerin levels increased to up to $24 \%$ of the dietary dry matter. Similarly, Van Cleef et al. (2014) did not find alterations in the average daily gain of beef cattle with elevation of the crude glycerin levels to up to $30 \%$ of the dietary dry matter. Lage et al. (2010), however, found a linear decrease in average daily gain with the increased crude glycerin levels $(0,3,6,9$, and $12 \%)$ in diets for intact Santa Inês lambs, which was associated with reduced dry matter intake due to the high content of fatty acids in the crude glycerin. All these results demonstrate the variability in the results obtained by the use of crude glycerin in ruminant diets. This variability may be associated with the species and/or animal categories, with the level of concentrate, with the type of feedstuff crude glycerin replaced, with the level of crude glycerin, and with the composition and nutritional value of the crude glycerin utilized in the different experimental diets.

The variation in average daily gain, which increased linearly, and the maintenance of dry matter intake, were responsible for the variation in feed conversion, which was reduced with the increased crude glycerin levels in the diets. 
The results presented in the literature for this characteristic vary widely. However, it can be observed that the most common results are those related to the lack of variation of feed efficiency with the use of crude glycerin levels in cattle diets (Françozo et al., 2013; Hales et al., 2013; Van Cleef et al., 2014).

The increase in average daily gain did not result in significant alterations in weight and carcass gain, loss of liquids from chilling, subcutaneous fat thickness, longissimus dorsi area, or carcass conformation, possibly because the slaughter weight was not significantly changed $(\mathrm{P}>0.05)$ with the increased crude glycerin levels in the diets. According to Petit et al. (1994), differences in carcass characteristics are rare when animals are slaughtered with similar body weights. Although the carcass characteristics are bound to the variation in body weight, it was expected that at least the loss of liquids from chilling would decrease with the increased dietary crude glycerin levels. This response would be expected because the crude glycerin increases the amount of fat in the carcass (Van Cleef et al., 2014), reducing the meat moisture content (Carvalho et al., 2014), which can result in a reduction of liquid loss from chilling. However, the similar fat cover degree, which was above the maximum $(<3 \mathrm{~mm})$ required by the industry, might have acted in a decisive manner for the similar chilling loss values. The similar fat cover degrees, in this regard, are coherent, since the crude glycerin promotes an increase in the amount of body fat by increasing the intramuscular fat content, which has been demonstrated in the literature results (Parsons et al., 2009; Van Cleef et al., 2014). The increased amount of intramuscular fat caused by the addition of crude glycerin to the diet is related to the increased ruminal production of gluconeogenic precursors such as propionate (Donkin, 2008; Chanjula et al., 2014). According to Pethick et al. (2004), the marbling fat has a preference for glucose and lactate carbons, whereas the subcutaneous fat prefers acetate carbons and acetyl units.

The results referring to the carcass characteristics were similar to most of the results reported in the literature (Górka et al., 2013; Leão et al., 2013; Egea et al., 2014; Eiras et al., 2014; Lage et al., 2014), which, as in the present study, did not show alterations in the slaughter weights with inclusion of crude glycerin in ruminant diets. Françozo et al. (2013) found that the slaughter weight was altered with the increased crude glycerin levels $(0,5$, and $12 \%$ of the dry matter) in the diets for Nellore young bulls, determining that the carcass weight and the longissimus dorsi area were altered; the diets containing 5\% crude glycerin provided the best results. Lage et al. (2010), in contrast, found that the carcass weight was reduced with the increased crude glycerin levels in lamb diets, resulting from the reduced animal performance in response to the reduced dry matter intake caused by the high fatty acid contents in the crude glycerin. Other conflicting results were obtained by Parsons et al. (2009), who observed that the carcass weight varied quadratically as the crude glycerin level in steer diets was increased, which was associated with the variation in animal performance. Despite the variation in carcass weight, Parsons et al. (2009) did not observe any alterations in the other carcass characteristics common to this study.

\section{Conclusions}

Inclusion of up to $240 \mathrm{~g} \mathrm{~kg}^{-1}$ crude glycerin in ground pearl millet grain-based diets for feedlot-finished Nellore young bulls elevates the average daily gain but does not change the main carcass characteristics of economic importance.

\section{Acknowledgments}

The authors thank Conselho Nacional de Desenvolvimento Científico e Tecnológico (CNPq) for the financial support.

\section{References}

Abo El-Nor, S.; Abughazaleh, A. A.; Potu, R. B.; Hastingsa, D.; Khattab, M. S. A. 2010. Effects of differing levels of glycerol on rumen fermentation and bacteria. Animal Feed Science and Technology 162:99-105.

Abughazaleh, A. A.; Abo El-Nor, S.; Ibrahim, S. A. 2011. The effect of replacing corn with glycerol on ruminal bacteria in continuous culture fermenters. Journal of animal Physiology and Animal Nutrition 95:313-319.

ANUALPEC - Anuário da pecuária brasileira. 2014. 21.ed. Instituto FNP, São Paulo.

AOAC - Association of Official Analytical Chemistry. 1995. Official methods of analysis. 16th ed. AOAC International, Arlington, VA.

Carvalho, J. R. R.; Chizzotti, M. L.; Ramos, E. M.; Machado Neto, O. R.; Lanna, D. P. D.; Lopes, L. S.; Teixeira, P. D. and Ladeira, M. M. 2014. Qualitative characteristics of meat from young bulls fed different levels of crude glycerin. Meat Science 96:977-983.

Casali, A. O.; Detmann, E.; Valadares Filho, S. C.; Pereira, J. C.; Henriques, L. T.; Freitas, S. G. and Paulino, M. F. 2008. Influência do tempo de incubação e do tamanho de partículas sobre os teores de compostos indigestíveis em alimentos e fezes bovinas obtidos por procedimentos in situ. Revista Brasileira de Zootecnia 37:335-342.

Chanjula, P.; Pakdeechanuan, P. and Wattanasit, S. 2014. Effects of dietary crude glycerin supplementation on nutrient digestibility, ruminal fermentation, blood metabolites, and nitrogen balance of goats. Asian Australasian Journal Animal Science 27:365-374.

Cochran, R. C.; Adams, D. C.; Wallace, J. D. and Galyean, M. L. 1986. Predicting digestibility diets with internal markers: 
evaluation of four potential markers. Journal of Animal Science 63:1476-1483.

Donkin, S. S. 2008. Glicerol from biodiesel production: The new corn for dairy cattle. Revista Brasileira de Zootecnia 37:280-286.

Egea, M.; Linares, M. B.; Garridoa, M. D.; Villodre, C.; Madridb, J.; Orengo, J.; Martínez, S. and Hernández, F. 2014. Crude glycerine inclusion in Limousin bull diets: Animal performance, carcass characteristics and meat quality. Meat Science 98:673-678.

Eiras, C. E.; Marques, J. A.; Prado, R. M.; Valero, M. V.; Bonafé, E. G.; Zawadzki, F.; Perotto, D. and Prado, I. N. 2014. Glycerine levels in the diets of crossbred bulls finished in feedlot: carcass characteristics and meat quality. Meat Science 96:930-936.

Françozo, M. C.; Prado, I. N.; Cecato, U.; Valero, M. V.; Zawadzki, F.; Ribeiro, O. L.; Prado, R. M. and Visentainer, J. V. 2013. Growth performance, carcass characteristics and meat quality of finishing bulls fed crude glycerin-supplemented diets. Brazilian Archives of Biology and Technology 56:327-336.

Górka, P.; McKinnon, J. J. and Penner, G. B. 2013. Use of high-lipid by-product pellets as a partial replacement for barley grain and canola meal in finishing diets for beef steers. Canadian Journal of

Hales, K. E.; Bondurant, R. G.; Luebbe, M. K.; Cole, N. A. and MacDonald, J. C. 2013. Effects of crude glycerin in steam-flaked corn-based diets fed to growing feedlot cattle. Journal of Animal Science 91:3785-3780.

Hill, G. M.; Newton, G. L.; Streeter, M. N.; Hanna, W. W.; Utley, P. R. and Mathis, M. J. 1996. Digestibility and utilization of pearl millet diets fed to finishing beef cattle. Journal of Animal Science 4:1728-1735.

Krehbiel, C. R. 2008. Ruminal and physiological metabolism of glycerin. Journal of Animal Science 86:392.

Lage, J. F.; Paulino, P. V. R.; Pereira, L. G. R.; Valadares Filho, S. C.; Oliveira, A. S.; Detmann, E. and Souza, N. K. P.; Moutinho Lima, J. C. 2010. Glicerina bruta na dieta de cordeiros terminados em confinamento. Pesquisa Agropecuária Brasileira 45:1012-1020.

Lage, J. F.; Berchielli, T. T.; San Vito, E.; Silva, R. A.; Ribeiro, A. F.; Reis, R. A.; Dallantonia, E. E.; Simonetti, L.R.; Delevatti, L. M. and Machado, M. 2014. Fatty acid profile, carcass and meat quality traits of young Nellore bulls fed crude glycerin replacing energy sources in the concentrate. Meat Science 96:1158- 1164.

Leão, J. P.; Neiva, J. N. M.; Restle, J.; Paulino, P. V. R.; Santana, A. E. M.; Miotto, F. R. C. and Missio, R. L. 2012. Consumo e desempenho de bovinos de aptidão leiteira em confinamento alimentados com glicerol. Ciência Animal Brasileira 4:421-428.

Leão, J. P.; Neiva, J. N. M.; Restle, J.; Missio, R. L.; Paulino, P. V. R.; Miotto, F. R. C.; Santana, A. E. M.; Sousa, L. F. and Alexandrino, A. 2013. Carcass and meat characteristics of different cattle categories fed diets containing crude glycerin. Semina Ciências Agrárias 34:431-444

Littell, R. C., Milliken, G. A., Stroup, W. W.; Wolfinger, R. D. and Schabenberger, O. 2006. SAS ${ }^{\circledR}$ for Mixed Models. 2nd ed. SAS Institute Inc., Cary, USA.

Lobley, G. E. 1992.Control of the metabolic fate of amino acids in ruminants: A review. Journal of Animal Science 70:3264-3275.
Missio, R. L.; Oliveira, M. D. S.; Sforcini, M. P. R.; Rennó, F. P.; Freitas Júnior, J. E.; Elejalde, D. A. G.; Ferrari, V. B. and Abud, G. C. 2012. Digestion of feed fractions and intake of heifers fed hydrolyzed sugarcane stored for different periods. Revista Brasileira de Zootecnia 41:1737-1746.

Morin, P.; Hamad, B.; Sapaly, G.; Rocha, M. G. C.; Pries de Oliveira, P. G.; Gonzalez, W. A.; Sales, E. A. and Essayem, N. 2007. Transesterification of rapeseed oil with ethanol. Applied Catalysis A: General 330:69-76.

Mota, C. J. A.; Silva, C. X. A. and Gonçalves, V. L. C. 2009 Gliceroquímica: novos produtos e processos a partir da glicerina de produção de biodiesel. Química Nova 32:639-648.

Müller, L. 1987. Normas para a avaliação de carcaças e concurso de carcaças de novilhos. 2.ed. Universidade Federal de Santa Maria, Santa Maria.

NRC - National Research Council. 1996. Nutrient requirements of beef cattle. 7th rev. ed. National Research Council, National Academy of Sciences, Washington, DC.

Oba, M. and Allen, M. S. 1999. Evaluation of the importance of the digestibility of neutral detergent fiber from forage: Effects on dry matter intake and milk yield of dairy cows. Journal of Dairy Science 82:589-59.

Parsons, G. L.; Shelor, M. K. and Drouillard, J. S. 2009. Performance and carcass traits of finishing heifers fed crude glycerin. Journal Animal Science 87:653-657.

Pethick, D. W.; Harper, G. S. and Oddy, V. H. 2004. Growth, development and nutritional manipulation of marbling in cattle: a review. Australian Journal Experimental Agriculture 44:704-715.

Petit, H. V.; Veira, D. M. and Yu, Y. 1994. Growth and carcass characteristics of beef steers fed silage and different levels of energy with or without protein supplementation. Journal of Animal Science 52:3221-3229.

Sniffen, C. J. Connor, J. D. O.; Van Soest, P. J.; Fox, D. G. and Russel, J. B. 1992. A net carbohydrate and protein system for evaluating cattle diets: II. Carbohydrate and protein availability. Journal of Animal Science 70:3562-3577.

Silva, A. H. G.; Restle, J.; Missio, R. L.; Bilego, U. O.; Fernandes, J. J. R.; Rezende, P. L. P.; Silva, R. M.; Pereira, M. L. R. and Lino, F. A. 2014. Milheto em substituição ao milho na dieta de novilhos confinados. Semina Ciências Agrárias 35:2077-2094.

Tan, H. W.; Abdul Aziz, A. R. and Aroua, M. K. 2013. Glycerol production and its applications as a raw material: A review. Renewable and Sustainable Energy Reviews 27:118-127.

Trabue, S.; Scoggin, K.; Tjandrakusuma, S.; Rasmussen, M. A. and Reilly, P. J. 2007. Ruminal fermentation of propylene glycol and glycerol. Journal of Agricultural and Food Chemistry 55:7043-7051.

Van Cleef, E. H. C. B.; Ezequiel, J. M. B.; D’aurea, A. P.; Fávaro, V. R. and Sancanari, J. B. I. D. 2014.Crude glycerin in diets for feedlot Nellore cattle. Revista Brasileira de Zootecnia 43:86-91.

Van Soest, P. J.; Robertson, J. B. and Lewis, B. A. 1991. Carbohydratemetodology, metabolism, and nutritional implications in dairy cattle. Journal of Dairy Science 74:3583-3597. 